\title{
POLA-POLA PADA SEGITIGA PASCAL DAN PEMBUKTIANNYA
}

\author{
Untung Trisna Suwaji ${ }^{1)}$ \\ ${ }^{1)}$ PPPPTK Matematika, Jl. Kaliurang KM 6, Sleman; untungtrisna@gmail.com
}

\begin{abstract}
Abstrak. Segitiga Pascal memiliki berbagai pola yang menarik. Artikel ini membahas beberapa pola yang dapat ditemukan pada segitiga Pascal dan pembuktiannya. Dalam proses pembelajaran, guru dapat mengajak siswa mengamati pola yang terbentuk, mencoba, menyusun dugaan, membuktikan, dan mengkomunikasikan hasil pengamatan sampai dengan proses pembuktiannya. Hal ini sejalan dengan proses pembelajaran yang disarankan dalam Kurikulum 2013 yaitu melalui proses mengamati, menanya, mencoba, menalar, dan mengomunikasikan.
\end{abstract}

Kata Kunci. Segitiga Pascal, Pola, Pembuktian.

\section{The Patterns on Pascal's Triangle and Their Proofs}

\begin{abstract}
Pascal's triangle has a variety of interesting patterns. This article discusses some of the patterns that might be found in Pascal's triangle and their proofs. In the teaching and learning process, teacher may invite students to observe these patterns, try the patterns to make generalization, make conjecture, prove the conjecture, and communicate the process to others. This procedure is appropriate with the teaching and learning process suggested in the Indonesian 2013 Curriculum.
\end{abstract}

Keywords. Pascal's triangle, patterns, proofs

\section{Pendahuluan}

Salah satu objek matematika yang banyak dikenal adalah Segitiga Pascal. Dinamakan Segitiga Pascal sebagai penghargaan kepada matematikawan Perancis Blaise Pascal (1623-1662) yang telah memaparkan hasil kerja di bidang ini dalam Traite $d u$ Triangle Arithmetique (Bondarenko, 1993). Risalah ini merupakan salah satu hasil awal di bidang teori peluang. Meskipun dinamakan sebagai Segitiga Pascal, pola Segitiga Pascal telah muncul dalam risalah karya Shih-Chieh Chu tahun 1303. Jika dirunut dari komponen penyusun Segitiga Pascal yaitu koefisien binomial, maka pembicaraan tentang ini telah muncul dalam Chandah-sutra dari India pada abad kedua atau ketiga sebelum Masehi (Plofker, 2009) dan buku Lilavati pada sekitar tahun 1150 (Knuth, 1997).

Berbagai pola dapat ditemukan dalam segitiga Pascal. Beberapa pola tersebut di antaranya, pola barisan bilangan asli, pola bilangan segitiga, pola bilangan tetrahedral, pola bilangan tetrahedral untuk ruang berdimensi lebih dari tiga (Gardner, 1989), pola barisan bilangan Fibonacci, pola jumlah semua elemen pada baris ke- $n$ adalah $2^{n}$, pola jumlah semua elemen di atas baris ke- $n$ adalah $2^{n}-1$, pola stik hoki, pola bilangan Catalan, dan pola bilangan ganjil pada setiap elemen pada baris $2^{k}-1$ (misal $k=3$, maka semua elemen pada baris ke $2^{3}-$ $1=7$ berupa bilangan ganjil). Jika dilacak lebih jauh, masih ada pola-pola lain yang dapat ditemukan. 
Tidak semua pola yang ditemukan pada Segitiga Pascal mudah dibuktikan. Pada artikel ini, akan dibahas beberapa pola beserta pembuktiannya.

\section{Rumusan Masalah}

Rumusan masalah pada artikel ini adalah "Apa saja pola-pola pada Segitiga Pascal dan bagaimana pembuktian pola-pola tersebut".

\section{Dasar Teori}

Dalam Aljabar, elemen-elemen pada Segitiga Pascal dapat dinyatakan sebagai koefisien dari hasil ekspansi binomial $(x+y)^{n}$. Sebagai contoh, $(x+y)^{1}=1 \cdot x+1 \cdot y,(x+y)^{2}=1$. $x^{2}+2 \cdot x y+1 \cdot y^{3}, \quad(x+y)^{3}=1 \cdot x^{2}+3 \cdot x^{2} y+3 \cdot x y^{2}+1 \cdot y^{3}$. Pada jenjang SMP, koefisien suku-suku di atas dapat diperoleh melalui penjabaran atau ekspansi menggunakan sifat distributif perkalian terhadap penjumlahan. Dengan melihat bahwa suku-suku ekspansi selalu berbentuk $x^{r} y^{n-r}$ dengan $r=1,2,3, \ldots, n$, maka koefisien ini dapat diinterpretasikan sebagai berikut. Disediakan $n$ tempat, maka koefisien $x^{r} y^{n-r}$ dapat dipandang sebagai banyak cara menempatkan $r$ buah $x$ dan sisanya diisi $y$. Misal untuk suku $x^{3} y^{2}$ pada ekspansi $(x+y)^{5}$ dapat dipandang sebagai banyaknya cara memilih 3 tempat untuk diisi $x$ dan otomatis sisanya 2 tempat diisi oleh $y$. Dalam cabang kombinatorika, hal ini dapat dinyatakan dengan notasi $\left(\begin{array}{l}5 \\ 3\end{array}\right)$ yang ekuivalen dengan $\left(\begin{array}{l}5 \\ 2\end{array}\right)$. Banyak cara memilih tersebut, jika dicacah akan diperoleh 10 cara.

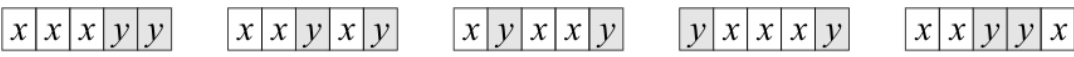

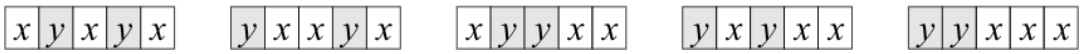

Gambar 1. Memilih 3 dari 5 tempat untuk diisi $x$

Berdasarkan ilustrasi di atas, untuk $n$ dan $r$ bilangan cacah dan $r \leq n$ maka koefisien $x^{r} y^{n-r}$ pada ekspansi $(x+y)^{n}$ adalah

$$
\left(\begin{array}{l}
n \\
r
\end{array}\right)=\frac{n !}{r ! \cdot(n-r) !}
$$

Dengan mendefinisikan $\left(\begin{array}{l}n \\ r\end{array}\right)=0$ untuk $r<0$ atau $n<r$, koefisien binomial $\left(\begin{array}{l}n \\ r\end{array}\right)$ memiliki sifat yang dinamakan sebagai identitas Pascal yaitu:

$$
\left(\begin{array}{l}
n-1 \\
r-1
\end{array}\right)+\left(\begin{array}{c}
n-1 \\
r
\end{array}\right)=\left(\begin{array}{l}
n \\
r
\end{array}\right)
$$

Bukti:

Dengan menggunakan (1) dan menjabarkan ruas kiri diperoleh

$$
\left(\begin{array}{c}
n-1 \\
r-1
\end{array}\right)+\left(\begin{array}{c}
n-1 \\
r
\end{array}\right)=\frac{(n-1) !}{(r-1) !(n-1-(r-1)) !}+\frac{(n-1) !}{r !(n-1-r) !}
$$




$$
\begin{aligned}
& =\frac{(n-1) !}{(r-1) !(n-r) !}+\frac{(n-1) !}{r !(n-1-r) !} \\
& =\frac{(n-1) ! r}{(r-1) ! r(n-r) !}+\frac{(n-1) !(n-r)}{r !(n-r-1) !(n-r)} \\
& =\frac{(n-1) ! r}{r !(n-r) !}+\frac{(n-1) !(n-r)}{r !(n-r) !}=\frac{(n-1) !(r+n-r)}{r !(n-r) !} \\
& =\frac{(n-1) ! n}{r !(n-r) !}=\frac{n !}{r !(n-r) !}=\left(\begin{array}{l}
n \\
r
\end{array}\right)
\end{aligned}
$$

Dengan adanya identitas ini menjadikan Segitiga Pascal lebih mudah dikonstruksi, dimulai dari elemen teratas $(n=0$ dan $r=0)$, elemen-elemen di bawahnya diperoleh dengan menjumlahkan dua elemen terdekat di atasnya. Sebagai contoh, bilangan 10 di baris ke-6 dapat diperoleh dengan dua elemen terdekat di baris ke-5, yaitu $6+4$.
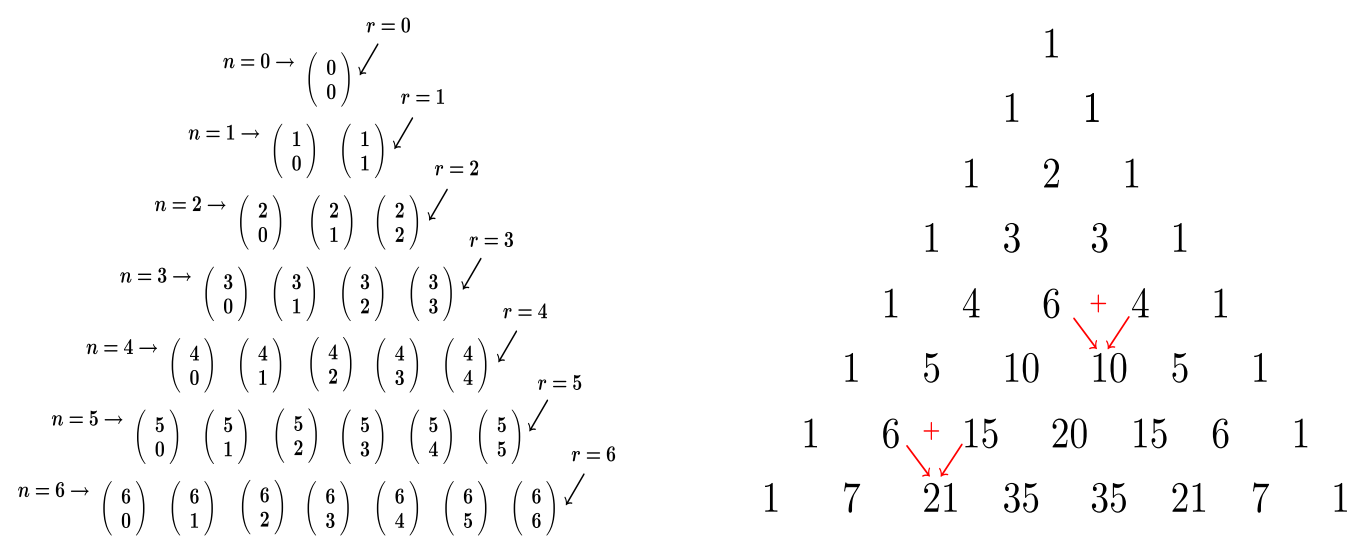

Gambar 2. Konstruksi Segitiga Pascal

\section{Pola pada Segitiga Pascal dan Pembuktiannya}

\subsection{Jumlah Elemen Masing-masing Baris}

Perhatikan jumlah elemen pada setiap baris.

$$
\begin{gathered}
1=1=2^{0} \\
1+1=2=2^{1} \\
1+2+1=4=2^{2} \\
1+3+3+1=8=2^{3} \\
1+4+6+4+1=16=2^{4}
\end{gathered}
$$

Teorema: $\sum_{i=0}^{n}\left(\begin{array}{l}n \\ i\end{array}\right)=2^{n}$

Bukti 1

Menggunakan $(a+b)^{n}=\sum_{i=0}^{n}\left(\begin{array}{c}n \\ i\end{array}\right) a^{n} b^{n-i}$

Dengan mengambil $a=b=1$ diperoleh 


$$
\begin{aligned}
(1+1)^{n} & =\sum_{i=0}^{n}\left(\begin{array}{l}
n \\
i
\end{array}\right) 1^{n} \cdot 1^{n-i} \\
2^{n} & =\sum_{i=0}^{n}\left(\begin{array}{c}
n \\
i
\end{array}\right)
\end{aligned}
$$

Bukti 2

Dengan menggunakan induksi matematika.

Langkah 1, ditunjukkan bahwa rumus berlaku untuk $n=0$.

$$
\sum_{i=0}^{0}\left(\begin{array}{l}
0 \\
i
\end{array}\right)=\left(\begin{array}{l}
0 \\
0
\end{array}\right)=\frac{0 !}{0 ! \cdot 0 !}=\frac{1}{1}=1=2^{0}
$$

Langkah 2, diasumsikan rumus berlaku untuk $n=k$, untuk sebarang bilangan bulat $k>0$

$$
\sum_{i=0}^{k}\left(\begin{array}{l}
k \\
i
\end{array}\right)=2^{k}
$$

Langkah 3, ditunjukkan bahwa rumus berlaku untuk $n=k+1$.

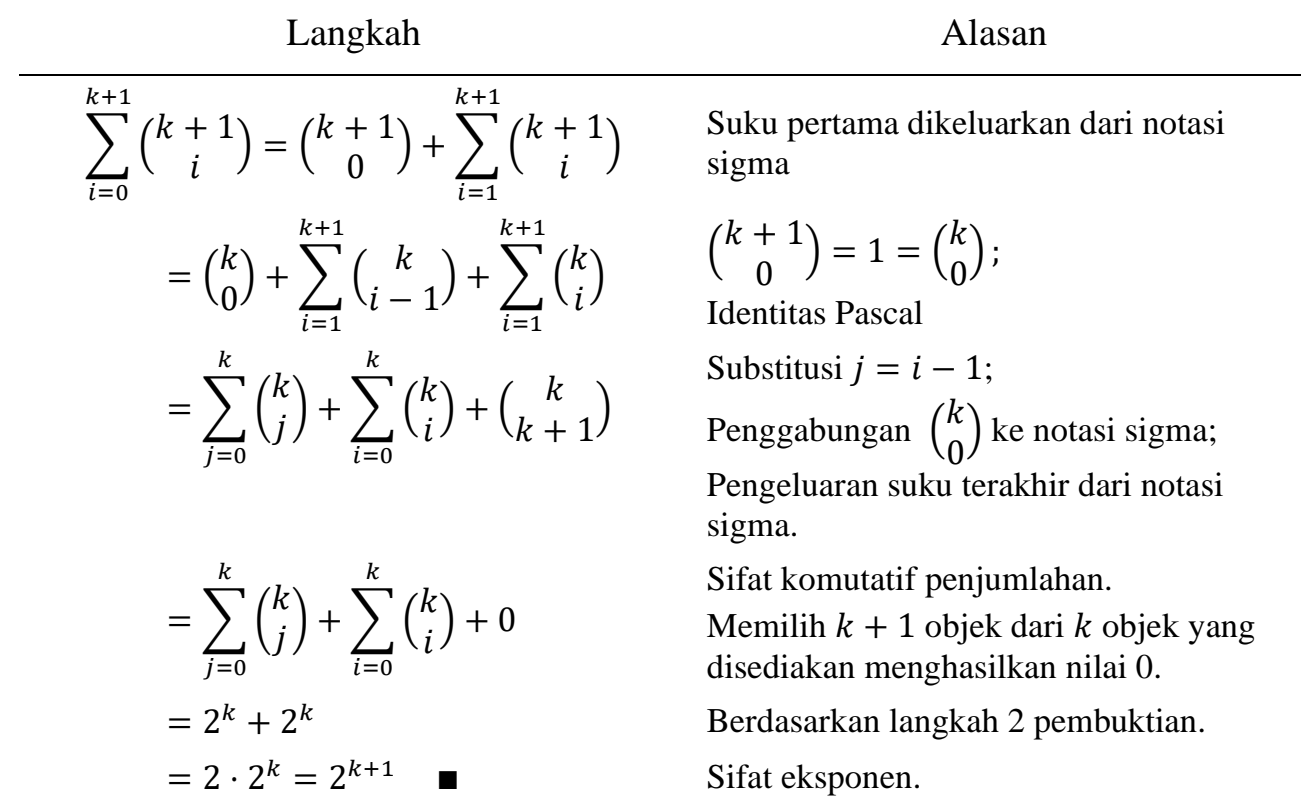

Jadi pernyataan $\sum_{i=0}^{n}\left(\begin{array}{c}n \\ i\end{array}\right)=2^{n}$ berlaku untuk setiap $n \geq 0, n$ bilangan bulat.

\subsection{Barisan Bilangan Fibonacci (BBF)}

Barisan bilangan Fibonacci merupakan satu barisan yang terkenal. Barisan ini banyak ditemukan di benda-benda alam seperti bunga pinus, nanas, pohon pepaya, pohon kelapa sawit, dll. Dinamakan barisan Fibonacci karena ditemukan dalam buku Liber Abaci (1202 M) karya Leonardo Fibonacci (Leonardo Pisano). Dalam buku tersebut disajikan masalah: 
"Diberikan sepasang kelinci yang baru lahir, carilah banyak kelinci dalam satu tahun jika 1) setiap pasang kelinci menjadi dewasa dalam waktu 1 bulan, 2) setiap pasang kelinci dewasa menghasilkan sepasang bayi kelinci setiap bulannya, 3) tidak ada kelinci yang mati." (Koshy, 2018). Solusi dari permasalahan ini, diperoleh banyak pasangan kelinci mulai dari bulan pertama, kedua, dan seterusnya sebanyak $1,1,2,3,5,8,13, \ldots$.

Barisan bilangan Fibonacci didefinisikan secara rekursif sebagai

$$
F_{1}=F_{2}=1 \text {, dan } F_{n}=F_{n-1}+F_{n-2} \text { untuk } n \geq 3 \text {. }
$$

Perhatikan jumlah elemen-elemen segitiga Pascal dalam arah "diagonal” berikut.
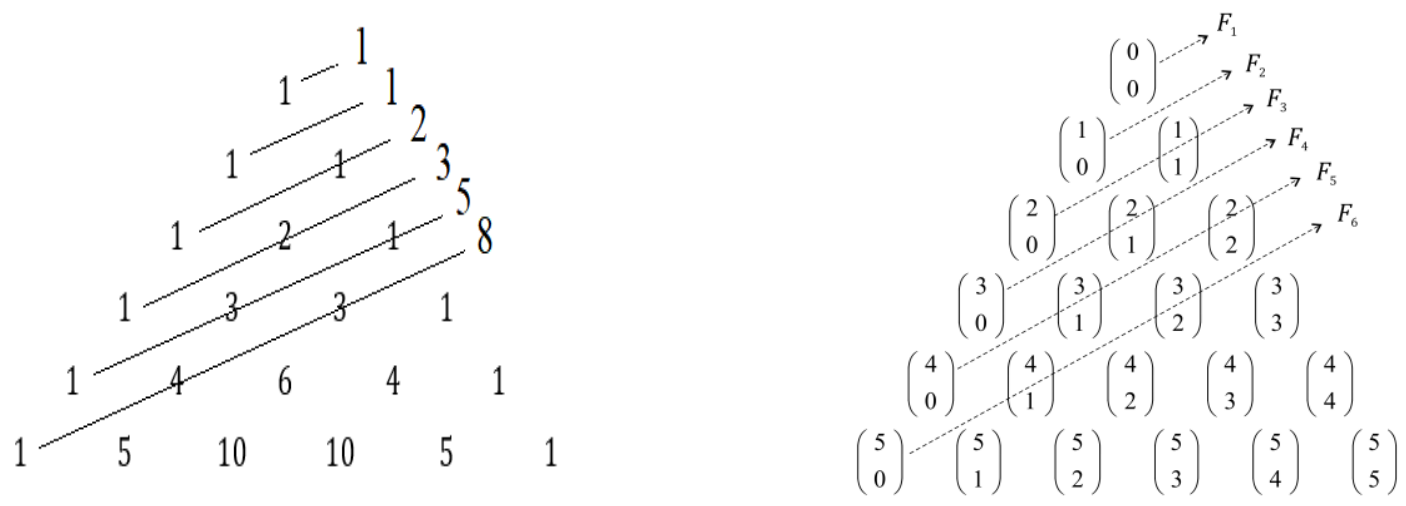

Gambar 3. BBF dalam Segitiga Pascal

Dengan mengamati pola

$$
\begin{aligned}
& F_{1}=\left(\begin{array}{l}
0 \\
0
\end{array}\right) \quad F_{3}=\left(\begin{array}{l}
2 \\
0
\end{array}\right)+\left(\begin{array}{l}
1 \\
1
\end{array}\right) \quad F_{5}=\left(\begin{array}{l}
4 \\
0
\end{array}\right)+\left(\begin{array}{l}
3 \\
1
\end{array}\right)+\left(\begin{array}{l}
2 \\
2
\end{array}\right) \quad F_{7}=\left(\begin{array}{l}
6 \\
0
\end{array}\right)+\left(\begin{array}{l}
5 \\
1
\end{array}\right)+\left(\begin{array}{l}
4 \\
2
\end{array}\right)+\left(\begin{array}{l}
3 \\
3
\end{array}\right) \\
& F_{2}=\left(\begin{array}{l}
1 \\
0
\end{array}\right) \quad F_{4}=\left(\begin{array}{l}
3 \\
0
\end{array}\right)+\left(\begin{array}{l}
2 \\
1
\end{array}\right) \quad F_{6}=\left(\begin{array}{l}
5 \\
0
\end{array}\right)+\left(\begin{array}{l}
4 \\
1
\end{array}\right)+\left(\begin{array}{l}
3 \\
2
\end{array}\right) \quad F_{8}=\left(\begin{array}{l}
7 \\
0
\end{array}\right)+\left(\begin{array}{l}
6 \\
1
\end{array}\right)+\left(\begin{array}{l}
5 \\
2
\end{array}\right)+\left(\begin{array}{l}
4 \\
3
\end{array}\right)
\end{aligned}
$$

Dapat disusun dugaan (konjektur)

$$
F_{n}=\sum_{i=0}^{\left\lfloor\frac{n-1}{2}\right\rfloor}\left(\begin{array}{c}
n-1-i \\
i
\end{array}\right)
$$

dengan $\lfloor p\rfloor$ menyatakan bilangan bulat terbesar yang kurang atau sama dengan $p$.

Contoh: $\left\lfloor\frac{3}{2}\right\rfloor=1,\left\lfloor\frac{1}{2}\right\rfloor=0,\lfloor 4\rfloor=4$.

Selanjutnya akan dibuktikan, apakah $\sum_{i=0}^{\left\lfloor\frac{n-1}{2}\right\rfloor}\left(\begin{array}{c}n-1-i \\ i\end{array}\right)$ adalah bilangan Fibonacci $F_{n}$. Jelas bahwa untuk $n=1$ dan 2, diperoleh $F_{1}=F_{2}=1$. Tinggal diperiksa apakah berlaku bentuk umum barisan Fibonacci $F_{n}=F_{n-2}+F_{n-1}$ untuk $n \geq 3$.

Untuk $n$ genap berlaku, $\left\lfloor\frac{n-1}{2}\right\rfloor=\frac{n-2}{2}, \quad\left\lfloor\frac{n-2}{2}\right\rfloor=\frac{n-2}{2}$, dan $\left\lfloor\frac{n-3}{2}\right\rfloor=\frac{n-2}{2}-1(* *)$, sehingga 


$$
\begin{gathered}
F_{n}=\sum_{i=0}^{\left\lfloor\frac{n-1}{2}\right\rfloor}\left(\begin{array}{c}
n-1-i \\
i
\end{array}\right)=\sum_{i=0}^{\frac{n-2}{2}}\left(\begin{array}{c}
n-1-i \\
i
\end{array}\right) \\
F_{n-1}=\sum_{i=0}^{\left\lfloor\frac{n-2}{2}\right\rfloor}\left(\begin{array}{c}
n-2-i \\
i
\end{array}\right)=\sum_{i=0}^{\frac{n-2}{2}}\left(\begin{array}{c}
n-2-i \\
i
\end{array}\right) \\
F_{n-2}=\sum_{i=0}^{\left\lfloor\frac{n-3}{2}\right\rfloor}\left(\begin{array}{c}
n-3-i \\
i
\end{array}\right)=\sum_{i=0}^{\frac{n-2}{2}-1}\left(\begin{array}{c}
n-3-i \\
i
\end{array}\right) .
\end{gathered}
$$

Selanjutnya,

Langkah

Penjelasan

$$
\begin{aligned}
F_{n-1}+F_{n-2} & =\sum_{i=0}^{\frac{n-2}{2}}\left(\begin{array}{c}
n-2-i \\
i
\end{array}\right)+\sum_{i=0}^{\frac{n-2}{2}-1}\left(\begin{array}{c}
n-3-i \\
i
\end{array}\right) \\
& =\left(\begin{array}{c}
n-2 \\
0
\end{array}\right)+\sum_{i=1}^{\frac{n-2}{2}}\left(\begin{array}{c}
n-2-i \\
i
\end{array}\right)+\sum_{i=0}^{\frac{n-2}{2}-1}\left(\begin{array}{c}
n-3-i \\
i
\end{array}\right) \\
& =\left(\begin{array}{c}
n-2 \\
0
\end{array}\right)+\sum_{i=1}^{\frac{n-2}{2}}\left(\begin{array}{c}
n-2-i \\
i
\end{array}\right)+\sum_{j=1}^{\frac{n-2}{2}}\left(\begin{array}{c}
n-2-j \\
j-1
\end{array}\right) \\
& \left.=\left(\begin{array}{c}
n-2 \\
0
\end{array}\right)+\sum_{j=1}^{\frac{n-2}{2}}\left(\begin{array}{c}
n-2-j \\
i
\end{array}\right)+\left(\begin{array}{c}
n-2-j \\
j-1
\end{array}\right)\right) \\
& =\left(\begin{array}{c}
n-2 \\
0
\end{array}\right)+\sum_{j=1}^{\frac{n-2}{2}}\left(\begin{array}{c}
n-1-j \\
j
\end{array}\right) \\
& =\left(\begin{array}{c}
n-1 \\
0
\end{array}\right)+\sum_{j=1}^{\frac{n-2}{2}}\left(\begin{array}{c}
n-1-j \\
j
\end{array}\right) \\
& \frac{n-2}{2}\left(\begin{array}{c}
\left.\frac{n-1}{2}\right\rfloor \\
n-1
\end{array}\right)=\sum_{j=1}^{n-1}\left(\begin{array}{l}
j-i \\
j
\end{array}\right)=F_{n}
\end{aligned}
$$

Keluarkan suku pertama dari notasi sigma.

Substitusi i dengan $j-1$

Sifat notasi sigma

Identitas Pascal

$\left(\begin{array}{c}n-1 \\ 0\end{array}\right)=\left(\begin{array}{c}n-2 \\ 0\end{array}\right)$

Menggunakan kesamaan (**)

Untuk $n$ ganjil berlaku, $\left\lfloor\frac{n-1}{2}\right\rfloor=\frac{n-1}{2},\left\lfloor\frac{n-2}{2}\right\rfloor=\frac{n-1}{2}-1$, dan $\left\lfloor\frac{n-3}{2}\right\rfloor=\frac{n-3}{2}=\frac{n-1}{2}-1(* * *)$, sehingga

$$
F_{n}=\sum_{i=0}^{\left\lfloor\frac{n-1}{2}\right\rfloor}\left(\begin{array}{c}
n-1-i \\
i
\end{array}\right)=\sum_{i=0}^{\frac{n-1}{2}}\left(\begin{array}{c}
n-1-i \\
i
\end{array}\right)
$$




$$
\begin{gathered}
F_{n-1}=\sum_{i=0}^{\left\lfloor\frac{n-2}{2}\right\rfloor}\left(\begin{array}{c}
n-2-i \\
i
\end{array}\right)=\sum_{i=0}^{\frac{n-1}{2}-1}\left(\begin{array}{c}
n-2-i \\
i
\end{array}\right) \\
F_{n-2}=\sum_{i=0}^{\left\lfloor\frac{n-3}{2}\right\rfloor}\left(\begin{array}{c}
n-3-i \\
i
\end{array}\right)=\sum_{i=0}^{\frac{n-1}{2}-1}\left(\begin{array}{c}
n-3-i \\
i
\end{array}\right) .
\end{gathered}
$$

Selanjutnya,

$$
\begin{aligned}
& \text { Langkah } \\
& F_{n-1}+F_{n-2}=\sum_{i=0}^{\frac{n-1}{2}-1}\left(\begin{array}{c}
n-2-i \\
i
\end{array}\right)+\sum_{i=0}^{\frac{n-1}{2}-1}\left(\begin{array}{c}
n-3-i \\
i
\end{array}\right) \\
& =\left(\begin{array}{c}
n-2 \\
0
\end{array}\right)+\sum_{i=1}^{\frac{n-3}{2}}\left(\begin{array}{c}
n-2-i \\
i
\end{array}\right)+\sum_{i=0}^{\frac{n-3}{2}}\left(\begin{array}{c}
n-3-i \\
i
\end{array}\right) \\
& =1+\sum_{i=1}^{\frac{n-3}{2}}\left(\begin{array}{c}
n-2-i \\
i
\end{array}\right)+\sum_{i=0}^{\frac{n-3}{2}-1}\left(\begin{array}{c}
n-3-i \\
i
\end{array}\right)+\left(\begin{array}{c}
n-3-\frac{n-3}{2} \\
\frac{n-3}{2}
\end{array}\right) \\
& =1+\sum_{i=1}^{\frac{n-3}{2}}\left(\begin{array}{c}
n-2-i \\
i
\end{array}\right)+\sum_{j=1}^{\frac{n-3}{2}}\left(\begin{array}{c}
n-2-j \\
j-1
\end{array}\right)+1 \\
& =1+\sum_{j=1}^{\frac{n-3}{2}}\left(\left(\begin{array}{c}
n-2-j \\
i
\end{array}\right)+\left(\begin{array}{c}
n-2-j \\
j-1
\end{array}\right)\right)+1 \\
& =1+\sum_{j=1}^{\frac{n-3}{2}}\left(\begin{array}{c}
n-1-j \\
j
\end{array}\right)+1 \\
& =\left(\begin{array}{c}
n-1 \\
0
\end{array}\right)+\sum_{j=1}^{\frac{n-1}{2}-1}\left(\begin{array}{c}
n-1-j \\
j
\end{array}\right)+\left(\begin{array}{c}
n-1-\frac{n-1}{2} \\
\frac{n-1}{2}
\end{array}\right) \\
& \left(\begin{array}{c}
n-1 \\
0
\end{array}\right)=1 \\
& \left(\begin{array}{l}
\frac{n-1}{2} \\
\frac{n-1}{2}
\end{array}\right)=1 \\
& =\sum_{j=0}^{\frac{n-1}{2}}\left(\begin{array}{c}
n-1-j \\
j
\end{array}\right)=F_{n}
\end{aligned}
$$

Dari kedua kasus untuk $n$ genap dan ganjil, ternyata sesuai definisi rekursif segitiga Pascal, sehingga pola $F_{n}=\sum_{i=0}^{\left\lfloor\frac{n-1}{2}\right\rfloor}\left(\begin{array}{c}n-1-i \\ i\end{array}\right)$ pada segitiga Pascal membentuk barisan bilangan Fibonacci. Terbukti. 


\subsection{Pola Stik Hoki}
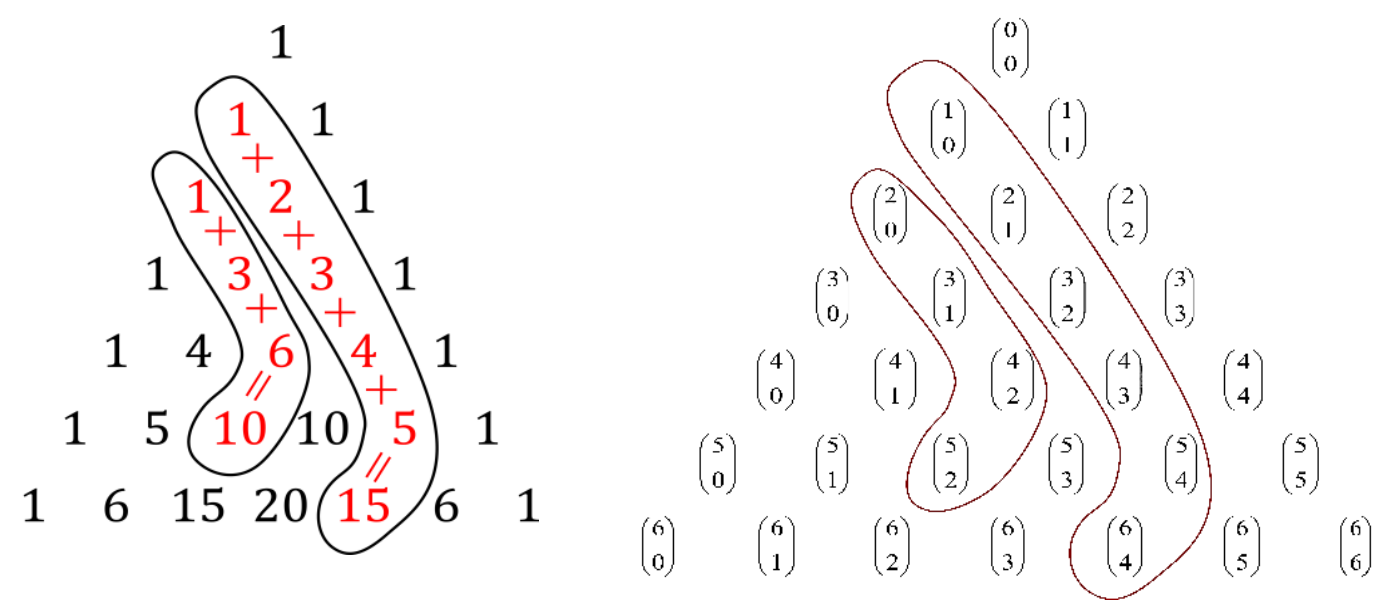

Gambar 4. Pola stik hoki dalam segitiga Pascal

Dari pola "stik hoki" yang terlihat $1+2+3+4+5=15, \quad 1+3+6=10$. Jika dalam bentuk notasi kombinasi, diperoleh $\left(\begin{array}{l}1 \\ 0\end{array}\right)+\left(\begin{array}{l}2 \\ 1\end{array}\right)+\left(\begin{array}{l}3 \\ 2\end{array}\right)+\left(\begin{array}{l}4 \\ 3\end{array}\right)+\left(\begin{array}{l}5 \\ 4\end{array}\right)=\left(\begin{array}{l}6 \\ 4\end{array}\right)$ dan $\left(\begin{array}{l}2 \\ 0\end{array}\right)+\left(\begin{array}{l}3 \\ 1\end{array}\right)+$ $\left(\begin{array}{l}4 \\ 2\end{array}\right)=\left(\begin{array}{l}5 \\ 2\end{array}\right)$. Jika pola ini diperumum, untuk suatu bilangan bulat cacah $n$ dan $p$ diperoleh bentuk

$$
\sum_{i=0}^{p}\left(\begin{array}{c}
n+i \\
i
\end{array}\right)=\left(\begin{array}{c}
n+p+1 \\
p
\end{array}\right)
$$

Bukti:

Akan dibuktikan dengan induksi matematika.

Untuk $p=0$, maka $\sum_{i=0}^{0}\left(\begin{array}{c}n+i \\ i\end{array}\right)=\left(\begin{array}{c}n+0+1 \\ 0\end{array}\right)$, diperoleh kesamaan $\left(\begin{array}{l}n \\ 0\end{array}\right)=\left(\begin{array}{c}n+1 \\ 0\end{array}\right)$ atau $1=1$. Jadi rumus berlaku untuk $p=0$.

Diasumsikan rumus berlaku untuk $p=k$, untuk sebarang bilangan bulat positif $k$.

$$
\sum_{i=0}^{k}\left(\begin{array}{c}
n+i \\
i
\end{array}\right)=\left(\begin{array}{c}
n+k+1 \\
k
\end{array}\right)
$$

Akan ditunjukkan bahwa rumus berlaku untuk $p=k+1$.

\begin{tabular}{cl} 
Langkah & \multicolumn{1}{c}{ Penjelasan } \\
\hline$\sum_{i=0}^{k+1}\left(\begin{array}{c}n+i \\
i\end{array}\right)=\left(\sum_{i=0}^{k}\left(\begin{array}{c}n+i \\
i\end{array}\right)\right)+\left(\begin{array}{c}n+k+1 \\
k+1\end{array}\right)$ & $\begin{array}{l}\text { Suku terakhir dikeluarkan dari } \\
\text { notasi sigma. }\end{array}$ \\
$=\left(\begin{array}{c}n+k+1 \\
k\end{array}\right)+\left(\begin{array}{c}n+k+1 \\
k+1\end{array}\right)$ & $\begin{array}{l}\text { Berdasarkan asumsi rumus } \\
\text { benar untuk } p=k .\end{array}$
\end{tabular}




$$
\begin{aligned}
& =\frac{(n+k+1) !}{(n+1) ! k !}+\frac{(n+k+1) !}{n !(k+1) !} \\
& =\frac{(n+k+1) !(k+1)}{(n+1) ! k !(k+1)}+\frac{(n+k+1) !(n+1)}{n !(n+1)(k+1) !} \\
& =\frac{(n+k+1) !((k+1+n)+1)}{(n+1) !(k+1) !} \\
& =\frac{((n+k+1)+1) !}{(n+1) !(k+1) !}=\frac{(n+(k+1)+1) !}{(n+1) !(k+1) !} \\
& =\frac{(n+(k+1)+1) !}{(n+(k+1)+1)-(k+1))(k+1) !} \\
& =\left(\begin{array}{c}
n+(k+1)+1 \\
(k+1)
\end{array}\right)
\end{aligned}
$$

Ketentuan $\left(\begin{array}{l}p \\ r\end{array}\right)=\frac{p !}{(p-r) ! r}$

Penyamaan penyebut

Sifat komutatif, asosiatif, dan distributif.

Sifat komutatif, asosiatif, dan distributif.

Menipulasi bentuk aljabar.

Sudah dapat ditunjukkan bahwa $\sum_{i=0}^{k+1}\left(\begin{array}{c}n+i \\ i\end{array}\right)=\left(\begin{array}{c}n+(k+1)+1 \\ (k+1)\end{array}\right)$, sehingga $\sum_{i=0}^{p}\left(\begin{array}{c}n+i \\ i\end{array}\right)=\left(\begin{array}{c}n+p+1 \\ p\end{array}\right)$ berlaku untuk setiap $p$ bilangan cacah. Terbukti.

\subsection{Bilangan Catalan}

Bilangan Catalan dapat diinterpretasikan sebagai banyak cara membagi poligon dengan $n+2$ sisi menjadi $n$ buah segitiga dengan sisi-sisi yang tidak berpotongan. Gambar di bawah menunjukkan ada 2 cara untuk segiempat, dan 5 cara untuk segilima.

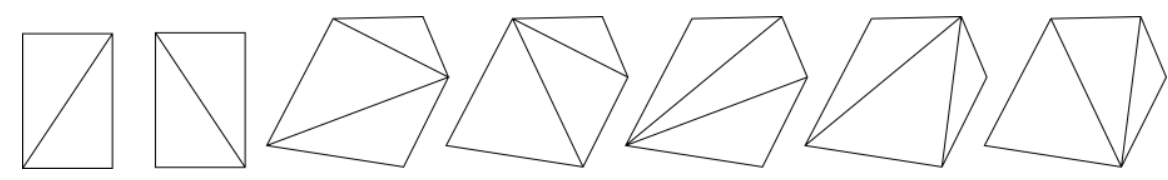

Gambar 5. Banyak cara membagi segiempat dan segilima

Interpretasi lain dari bilangan Catalan adalah banyak lintasan terpendek sepanjang $2 n$ melalui grid berukuran $n \times n$ tanpa memotong diagonal utama. (Weisstein, 2020)
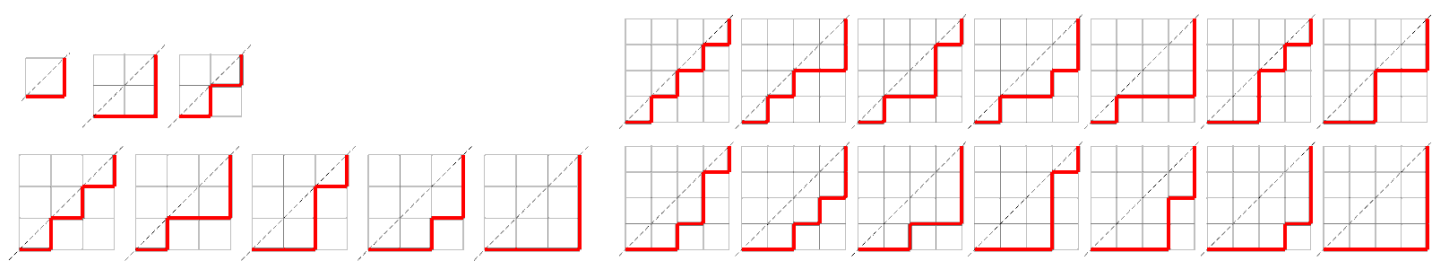

Gambar 6. Banyak lintasan terpendek sepanjang $2 n$ tanpa memotong diagonal utama (untuk

$$
n=1,2,3,4)
$$

Bilangan Catalan membentuk barisan, dengan rumus suku ke- $n$ adalah $C_{n}=\frac{1}{n+1}\left(\begin{array}{c}2 n \\ n\end{array}\right)$.

Dengan rumus ini, maka barisan bilangan Catalan adalah $1,2,5,14,42,132, \ldots$. 
Bilangan Catalan dapat ditemukan dalam segitiga Pascal. Perhatikan gambar berikut.

\begin{tabular}{|c|c|c|c|}
\hline \multicolumn{4}{|c|}{1} \\
\hline & & 1 & 1 \\
\hline & & 1 & $2-1$ \\
\hline & & 13 & $3-1$ \\
\hline & 1 & 4 & $6-4 \quad 1$ \\
\hline & & $5 \quad 10$ & $10-5$ \\
\hline 1 & 6 & 15 & $20-15 \quad 6$ \\
\hline 7 & 7 & $21 \quad 35$ & $35-21$ \\
\hline
\end{tabular}

Perhatikan pola yang terbentuk untuk $n$ ganjil

$$
\left(\begin{array}{l}
1 \\
1
\end{array}\right)=1 ;\left(\begin{array}{l}
3 \\
2
\end{array}\right)-\left(\begin{array}{l}
3 \\
3
\end{array}\right)=2 ;\left(\begin{array}{l}
5 \\
3
\end{array}\right)-\left(\begin{array}{l}
5 \\
4
\end{array}\right)=5 ; \quad\left(\begin{array}{l}
7 \\
4
\end{array}\right)-\left(\begin{array}{l}
7 \\
5
\end{array}\right)=14
$$

Sedangkan untuk $n$ genap

$$
\left(\begin{array}{l}
2 \\
1
\end{array}\right)-\left(\begin{array}{l}
2 \\
2
\end{array}\right)=1 ;\left(\begin{array}{l}
4 \\
2
\end{array}\right)-\left(\begin{array}{l}
4 \\
3
\end{array}\right)=2 ;\left(\begin{array}{l}
6 \\
3
\end{array}\right)-\left(\begin{array}{l}
6 \\
4
\end{array}\right)=5 ; \quad\left(\begin{array}{l}
8 \\
4
\end{array}\right)-\left(\begin{array}{l}
8 \\
5
\end{array}\right)=14
$$

Hasil pengurangan elemen-elemen di atas membentuk barisan Catalan.

Selanjutnya akan dibuktikan untuk $n>1$,
a. $\left(\begin{array}{c}2 n-1 \\ n\end{array}\right)-\left(\begin{array}{c}2 n-1 \\ n+1\end{array}\right)=\frac{1}{n+1} \cdot\left(\begin{array}{c}2 n \\ n\end{array}\right)$
b. $\left(\begin{array}{c}2 n \\ n\end{array}\right)-\left(\begin{array}{c}2 n \\ n+1\end{array}\right)=\frac{1}{n+1} \cdot\left(\begin{array}{c}2 n \\ n\end{array}\right)$

Bukti untuk bagian $b$.

$$
\begin{aligned}
\left(\begin{array}{c}
2 n \\
n
\end{array}\right)-\left(\begin{array}{c}
2 n \\
n+1
\end{array}\right) & =\frac{(2 n) !}{n ! n !}-\frac{(2 n) !}{(n+1) !(n-1) !} \\
& =\frac{(2 n) !(n+1)}{n ! n !(n+1)}-\frac{(2 n) ! n}{n !(n+1)(n-1) ! n} \\
& =\frac{(2 n) !(n+1)}{n ! n !(n+1)}-\frac{(2 n) ! n}{n ! n !(n+1)}=\frac{(2 n !)(n+1-n)}{n ! n !(n+1)} \\
& =\frac{1}{n+1} \cdot \frac{(2 n) !}{n ! n !}=\frac{1}{n+1} \cdot\left(\begin{array}{c}
2 n \\
n
\end{array}\right)
\end{aligned}
$$

Bukti untuk bagian a.

$$
\left(\begin{array}{c}
2 n-1 \\
n
\end{array}\right)-\left(\begin{array}{c}
2 n-1 \\
n+1
\end{array}\right)=\frac{(2 n-1) !}{n !(2 n-1-n) !}-\frac{(2 n-1) !}{(n+1) !(2 n-1-(n+1)) !}
$$




$$
\begin{aligned}
& =\frac{(2 n-1) !}{n !(n-1) !}-\frac{(2 n-1) !}{(n+1) !(n-2) !} \\
& =\frac{(2 n-1) !(n+1)}{n ! \cdot(n+1) \cdot(n-1) !}-\frac{(2 n-1) !(n-1)}{(n+1) !(n-2) ! \cdot(n-1)} \\
& =\frac{(2 n-1) !(n+1-(n-1))}{(n+1) !(n-1) !}=\frac{(2 n-1) ! \cdot 2}{n ! \cdot(n+1) \cdot(n-1) !} \\
& =\frac{(2 n-1) ! \cdot 2 n}{n ! \cdot(n+1) \cdot(n-1) ! \cdot n}=\frac{(2 n) !}{(n+1) \cdot n ! \cdot n !} \\
& =\frac{1}{n+1} \cdot\left(\begin{array}{c}
2 n \\
n
\end{array}\right)
\end{aligned}
$$

\section{Pembelajaran Pola Segitiga Pascal di Sekolah}

Meskipun topik bahasan di sini tidak terdapat dalam buku teks matematika SMA, namun topik ini dapat dijadikan bahan untuk mendukung proses pembelajaran di sekolah. Hal ini sejalan dengan rumusan Kompetensi Inti 4 (keterampilan), dimana kompetensi yang akan dicapai adalah mengolah, menalar, dan menyaji dalam ranah konkret dan ranah abstrak terkait dengan pengembangan dari yang dipelajarinya di sekolah secara mandiri, bertindak secara efektif dan kreatif, serta mampu menggunakan metoda sesuai kaidah keilmuan. (Permendikbud no. 37 tahun 2018). Berdasarkan rumusan ini, semestinya kompetensi siswa SMA bisa melampaui apa yang minimum harus dipelajari di sekolah.

Perlu diakui masih banyak tantangan untuk mewujudkan kompetensi siswa sesuai standar yang diinginkan. Salah satunya adalah faktor kesiapan guru. Tidak dipungkiri, bahwa kemampuan pembuktian masih menjadi masalah di kalangan guru-guru kita. Penelitian Sumardyono tahun 2017 yang melibatkan 23 responden guru matematika SMA/SMK, dengan perintah membuktikan bahwa $1+2+3+\cdots+n=\frac{n(n+1)}{2}$ menggunakan induksi matematika, terdapat 15 responden $(65 \%)$ tidak mengetahui induksi matematis. Hasil wawancara langsung terhadap yang tidak tahu ini, hampir semua mengatakan lupa dengan metode tersebut. Sementara itu dari sisanya yang mencoba membuktikan dengan induksi tidak satupun yang berhasil membuktikan secara lengkap dan benar. (Sumardyono, 2018).

Dalam pembelajaran topik pola pada Segitiga Pascal dapat diterapkan di kelas XI pada topik pembuktian dengan Induksi Matematika, dan kelas XII pada materi permutasi dan kombinasi. Siswa dapat diperkenalkan bahwa matematika bisa dilihat sebagai bahasa yang menggambarkan pola-pola di alam dan pola yang ditemukan oleh pikiran manusia. Pola-pola tersebut dapat berupa nyata atau pun khayalan, visual atau pun mental, statis atau pun dinamis, kualitatif atau pun kuantitatif, murni memiliki manfaat atau pun tidak lebih dari sekedar untuk rekreasi. (Lange, 2006). Pada jenjang SMA, setelah mengamati pola, seyogyanya tidak berhenti sampai membuat dugaan. Dugaan harus dibuktikan agar dapat diterima sebagai pernyataan matematika yang benar (dalam beberapa kasus tidak selalu memungkinkan pada suatu jenjang pendidikan). (Pavlekovic, 1998). Alur belajar yang dapat diterapkan dalam hal ini adalah mengidentifikasi pola, membuat dugaan, menyediakan argumen non-bukti, dan memberikan bukti. Alur ini merupakan bagian dari proses dan membangun pengetahuan matematika. (Stylianides, 2008). 


\section{Simpulan}

Segitiga Pascal memiliki berbagai pola yang dapat dieksplorasi untuk proses pembelajaran di sekolah. Pola yang telah dibahas antara lain jumlah setiap baris, barisan bilangan Fibonacci, Stik Hoki, dan bilangan Catalan. Alur belajar yang dapat diterapkan adalah siswa diajak untuk mengamati pola, mencoba pola yang terbentuk dalam berbagai posisi, menyusun dugaan, menyusun bukti, hingga mengomunikasikan, baik dalam bentuk tertulis maupun lisan. Dalam penerapannya, mungkin masih banyak kendala dikarenakan tidak biasanya aktivitas belajar di sekolah terkait dengan masalah pembuktian. Dengan disajikannya pembuktian pada artikel ini diharapkan dapat memberi pencerahan kepada guru dan siswa untuk kembali ke esensi belajar matematika, yaitu memahami dan menalar.

\section{Daftar Pustaka}

Bondarenko, B. A. (1993). Generalized Pascal Triangles and Pyramids (Diterjemahan dari Obobshchennye Treugol'niki I Piramidy Paskalya). Fibonacci Association.

Brahier, D. J. (2016). Teaching Secondary and Middle School Mathematics, 5th ed. New York: Rouledge.

Gardner, M. (1989). Mathematical Carnival. Washington: The Mathematical Association of America.

Knuth, D. E. (1997). The Art of Computer Programming Vol. 1 Fundamental Algorithms (3rd ed.). Addison-Wesley.

Koshy, T. (2018). Fibonacci and Lucas Numbers with Applications, Vol. 1, 2nd ed. New Jersey: Wiley.

Lange, J. d. (2006). Mathematical Literacy for Living from OECD-PISA Perspective. Tsukuba Journal of Educational Study in Mathematics. Vol. 25, 13-35.

Pavlekovic, M. (1998). An Approach to Mathematical Induction - Starting from the Early Stages of Teaching Mathematics. Mathematical Communication 3, 140.

Plofker, K. (2009). Mathematics in India. New Jersey: Princenton University Press.

Stylianides, G. J. (2008). An Analytic Framework of Reasoning-and-Proving. For the Learning of Mathematics 28, 9.

Sumardyono. (2018). Kemampuan Guru dalam Menyusun Bukti Matematis. Idealmathedu, 510-522.

Weisstein, E. W. (2020, 09 01). https://mathworld.wolfram.com/DyckPath.html. Diambil kembali dari MathWorld. 